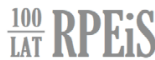

\author{
MONIKA MOSKA*, MICHAŁ PRZYBYE ${ }^{* *}$
}

\section{CHARAKTER PRAWNY OPLATY DODATKOWEJ ZA BRAK ODPOWIEDNIEGO DOKUMENTU PRZEWOZU}

\section{WPROWADZENIE}

Przepis art. 33a ust. 3 Prawa przewozowego ${ }^{1}$ stanowi podstawę prawna roszczenia przewoźnika wobec osoby jadącej bez ważnego dokumentu podróży (biletu) o zapłatę opłaty dodatkowej. Charakter prawny tej opłaty budzi liczne wątpliwości w doktrynie, a przedstawione w tej kwestii koncepcje zdają się wymagać pogłębienia. W szczególności spotkać można poglądy, że stanowi ona karę umowną w rozumieniu art. $483 \S 1$ k.c. ${ }^{2}$ czy też sui generis sankcję prawa cywilnego $^{3}$. Aby udzielić możliwie wyczerpujacej odpowiedzi na pytanie o charakter prawny tytułowej opłaty, należy zastanowić się przede wszystkim nad jej źródłem i scharakteryzować sytuację prawna, w jakiej znajduje się osoba podróżująca „na gapę”.

Wskazane zagadnienia stanowią dla autorów punkt wyjścia do podjęcia rozważań nad bardziej ogólnymi kwestiami, takimi jak definicja czynności prawnej czy granice między prawem cywilnym a prawem publicznym, w tym także nad problemem rozróżnienia działalności państwa w sferach imperium i dominium.

Za wyborem zarysowanego tematu przemawia ponadto jego duża doniosłość praktyczna (sytuacje wyłudzenia przejazdu zdarzają się niestety dość

* Monika Moska, Uniwersytet im. Adama Mickiewicza w Poznaniu, monmos@amu.edu.pl, https://orcid.org/0000-0002-2406-5242

** Michał Przybył, Uniwersytet im. Adama Mickiewicza w Poznaniu, michal.andrzej.przybyl@gmail.com, https://orcid.org/0000-0002-2406-5242

1 Ustawa z 15 listopada 1984 r. - Prawo przewozowe, t.jedn.: Dz. U. 2017, poz. 1983 ze zm. (dalej jako: Pr.przew.).

2 Ostrowska (1998): 16.

3 Radwański (1998): 19; Szanciło (2008): 175-176; Jaworski (2012): 76-77; Ambrożuk (2014): 145-146; podobnie Górski, Wesołowski (2009): 102. 
często) oraz aktualność w skali unijnej (niedawno podobnymi rozważaniami zajmował się Trybunał Sprawiedliwości Unii Europejskiej).

Podstawowa metodę badawczą wykorzystywaną w niniejszym artykule stanowi metoda dogmatycznoprawna. Interpretacja tekstu prawnego następuje przede wszystkim na gruncie derywacyjnej koncepcji wykładni.

\section{SYTUACJA PRAWNA OSÓB KORZYSTAJĄCYCH Z USŁUG PRZEWOŹNIKA BEZ ZAMIARU UISZCZENIA WYNAGRODZENIA}

W pierwszej kolejności należy zastanowić się, czy, a jeśli tak, to jaki ewentualnie stosunek prawny łączy przewoźnika z osoba, która wprawdzie zajęła miejsce w środku transportowym, lecz nie miała zamiaru uiszczenia należności przewozowych. W szczególności istotne jest to, czy dochodzi w takim przypadku do zawarcia umowy przewozu per facta concludentia. Pochylenie się nad tym problemem nie stanowi jedynie ars gratia artis, przyjęcie bowiem określonego stanowiska $\mathrm{w}$ tej sprawie determinuje tak istotne z praktycznego punktu widzenia kwestie, jak chociażby to, czy podmiot podróżujący w opisany sposób jest konsumentem i czy w konsekwencji sąd powinien badać przedawnienie roszczenia przewoźnika o uiszczenie opłaty dodatkowej z urzędu czy na zarzut drugiej strony (art. $117 \S 2^{1}$, art. $117^{1}$ k.c.).

Zgodnie z art. 16 ust. 1 Pr.przew. umowę przewozu zawiera się przez nabycie biletu na przejazd przed rozpoczęciem podróży lub spełnienie innych określonych przez przewoźnika lub organizatora publicznego transportu zbiorowego warunków dostępu do środka transportowego, a w razie ich nieustalenia - przez samo zajęcie miejsca w środku transportowym. Wskazany przepis określa możliwe sposoby złożenia oświadczeń woli. Podstawowym sposobem jest nabycie biletu, które nie stanowi jednak przesłanki zawarcia umowy i ma znaczenie jedynie dowodowe. Umowa przewozu ma charakter konsensual$n y^{5}$, do jej zawarcia dochodzi na skutek złożenia zgodnych oświadczeń woli stron (tj. przewoźnika i podróżnego). Bilet, będący znakiem legitymacyjnym ${ }^{6}$, potwierdza jedynie treść umowy przewozu, której forma może być dowolna (np. ustna). Niekiedy nabycie biletu nie jest wystarczające. Przewoźnik może określić inne warunki skorzystania ze środka transportu, może przykładowo wymagać skasowania biletu. Istnieją też sytuacje, gdy do zawarcia umowy

${ }^{4}$ Wyrok TSUE z 7 listopada 2019 r., Nationale Maatschappij der Belgische Spoorwegen, w sprawach połaczonych od C-349/18 do C-351/18, EU:C:2019:936 (dalej jako: wyrok TSUE z 7 listopada 2019 r., Nationale Maatschappij der Belgische Spoorwegen).

${ }_{5}$ Ambrożuk (2014): 83; Szanciło (2008): 101. Poza ramami niniejszego artykułu autorzy chcieliby natomiast zostawić wątpliwości dotyczące tego, kto - przewoźnik czy podróżny - składa ofertę zawarcia umowy. Zasygnalizować wypada jedynie, że w doktrynie przeważa opinia, że działania przewoźnika polegające np. na ogłoszeniu rozkładu jazdy i taryfy przewozowej stanowią zaproszenie do zawarcia umowy; zob. Radwański, Panowicz-Lipska (2013): 234.

${ }^{6}$ Radwański, Panowicz-Lipska (2013): 369. 
dochodzi przez samo zajęcie miejsca w środku transportu, a przewoźnik nie wymaga posiadania przez podróżującego żadnych dokumentów przewozu. Tak się dzieje chociażby w przypadku przewozów dokonywanych taksówkami ${ }^{7}$ Ta ostatnia grupa sytuacji pozostanie jednak poza ramami niniejszego artykułu, z uwagi na to, że przewoźnikowi nie będzie wówczas nigdy przysługiwać roszczenie o uiszczenie opłaty dodatkowej, gdyż do okoliczności zastosowania wyinterpretowanej z art. 33a ust. 3 Pr.przew. normy prawnej należy istnienie obowiązku posiadania dokumentu przewozowego.

Skoro - jak zostało powyżej podkreślone - (skasowany) bilet pełni funkcję wyłącznie dowodowa, nie można a limine przesądzać, że osoba podróżujaca bez takiego dokumentu nie zawarła umowy przewozu. Może się na przykład okazać, że zgubiła ona bilet albo że mimo opłacenia przez Internet przejazdu to przewoźnik nie wysłał jej biletu w odpowiednim terminie. Podróżny może wówczas wszelkimi środkami dowodowymi wykazywać, że jednak doszło do zawarcia umowy. Odmiennie należy natomiast ocenić sytuację, gdy dana osoba skorzystała ze środka transportu, pomimo że nigdy nie uiściła należności przewozowych (nie podjęła żadnych starań w tym celu). Wydaje się, że należy wówczas przyjąć, że osoba taka nie złożyła w ogóle oświadczenia woli. Zgodnie z dominujaccym obecnie w polskiej doktrynie stanowiskiem obiektywnym oświadczeniem woli jest ,zachowanie podmiotu prawa cywilnego, majace status czynności konwencjonalnej, której przynajmniej niektóre reguły sensu skonstruowane są przez system prawny, polegające na wytworzeniu znaku, z którym określone reguły znaczeniowe wiążą znaczenie (sens) ustanowienia przynajmniej jednej normy, mającej doniosłość w obszarze prawa cywilnego".

Z semiotycznego punktu widzenia oświadczenie woli jest zatem rozumiane jako znak. Tradycyjnie w polskiej teorii prawa znakiem nazywamy dostrzegalny układ rzeczy czy zjawisko spowodowane przez kogoś ze względu na to, że jakieś wyraźnie ustanowione czy zwyczajowo ukształtowane reguły nakazuja wiązać z tym układem rzeczy czy zjawiskiem myśli określonego typu ${ }^{9}$. Na podstawie przywołanej definicji zauważyć można, że na pojęcie znaku składaja się: jego materialny substrat oraz reguły znaczeniowe, które nakazują wiązać z tym substratem określone myśli. Nie ma przy tym konieczności, aby podmiot wytwarzający ów materialny substrat znaku zdawał sobie sprawę z istnienia w danym układzie społecznym odpowiednich reguł znaczeniowych. Ponadto oświadczenie woli może być także rozumiane jako czynność konwencjonalna, czyli taka czynność psychofizyczna albo czynność konwencjonalna niższego stopnia, której reguły sensu każą przypisywać określony sens kulturowy ${ }^{10}$.

W analizowanym przez nas przypadku osoby podróżującej bez (skasowanego) biletu bez wątpienia mamy do czynienia z czynnościa psychofizyczna (materialnym substratem ewentualnego znaku), ponieważ osoba taka kolejno wchodzi do środka transportowego i zajmuje w nim miejsce. Rozważyć należy,

\footnotetext{
7 Ambrożuk (2014): 84.

8 Radwański, Mularski (2019): 34-35.

9 Ziembiński (2012): 14.

10 Wronkowska (2005): 12-13.
} 
czy istnieją ponadto odpowiednie reguły sensu (czy też reguły znaczeniowe), które nakazywałyby traktować czynność zajęcia miejsca w środku transportowym jako zawarcie przez podróżnego umowy przewozu. Owe reguły mogą być wyraźnie ustanowione, ale mogą się także ukształtować zwyczajowo w danej społeczności ${ }^{11}$. W odniesieniu do umowy przewozu istnieją reguły sensu, wskazujące, jakie zachowanie należy poczytywać za złożenie oświadczenia woli przez podróżnego, które zostały ustanowione przez ustawodawcę w przywołanym już art. 16 Pr.przew. Podkreślone jednak zostało dobitnie, że wymienione w tym przepisie sposoby zawarcia umowy (czynności traktowane jako złożenie oświadczenia woli) pełnią funkcję tylko dowodowa. Zawarcie umowy w inny sposób jest możliwe, ale musi zostać przez strony udowodnione. Nie można więc a limine wykluczyć, że w kulturze danego społeczeństwa uformowałyby się inne, zwyczajowe reguły sensu, które - istniejąc niejako obok tych stanowionych - nakazywałyby uznawać także pewne inne czynności psychofizyczne za oświadczenie woli zawarcia umowy przewozu. Jednakże wydaje się, że skoro ustawodawca wskazał już reguły sensu konstruujące omawianą czynność konwencjonalna, to intuicyjnie niezwykle mało prawdopodobne jest wykształcenie się paralelnych zwyczajowych reguł sensu, które wskazywałyby alternatywny sposób ważnego dokonania tej samej czynności konwencjonalnej, a przynajmniej w omawianym przypadku nie wydaje się, aby takowe istniały.

Wyłudzenie przewozu porównać można do sytuacji kradzieży w sklepie. Skąd wiadomo, że złodziej nie składa oświadczenia woli zawarcia umowy sprzedaży? Prawdopodobnie stąd, że zamiast podejść z towarem do kasy, ukrywa go, potajemnie wynosi i nie podejmuje żadnych starań, by dokonać płatności. W przypadku przejazdu środkiem transportu bez zamiaru uiszczenia należności przewozowych sytuacja prima facie może nie wydawać się równie czytelna, ponieważ obiektywnie nie jest możliwe ukrycie faktu skorzystania z usług przewoźnika. Należy jednak zwrócić uwagę na to, czy podróżujący swoim zewnętrznym zachowaniem wyraził w jakikolwiek (także pozawerbalny) sposób gotowość nie tylko do skorzystania z usługi, lecz również do spełnienia świadczenia wzajemnego. Jeśli ani razu nie podjął próby nabycia biletu czy uiszczenia zapłaty, niezasadne byłoby doszukiwanie się w jego zachowaniu oświadczenia woli zawarcia umowy odpłatnej.

Za wskazaną interpretacją zachowania osoby podróżującej „na gapę” przemawia także ogólna zasada nemo ex suo delicto meliorem suam condicionem facere potest. Wydaje się, że sprzeczna z systemem wartości przypisywanym racjonalnemu prawodawcy byłaby sytuacja, w której osoba wyłudzająca przejazd uzyskiwałaby jako konsument dodatkową ochronę w relacji z przewoźnikiem właśnie na podstawie jej nieuczciwego zachowania się.

Konkludując, należy zauważyć, że w sytuacji gdy przewoźnik określił pewne warunki dostępu do środka transportowego (np. przez nabycie czy skasowanie biletu), samo zajęcie miejsca w takim środku transportowym nie może być poczytywane za oświadczenie woli, ponieważ brak jest odpowiednich reguł sensu, które nakazywałyby traktować tę czynność psychofizyczną jako

\footnotetext{
11 Wronkowska (2005): 12-13.
} 
określoną czynność konwencjonalną. Osoba wyłudzająca przewóz nie składa zatem żadnego oświadczenia woli ${ }^{12}$, a w szczególności nie wyraża zamiaru zawarcia umowy przewozu nieodpłatnego. Tym samym należy podzielić poglądy, wyrażane przez wielu przedstawicieli nauki, że w przypadku tzw. przejazdu na gapę nie dochodzi do zawarcia umowy przewozu ${ }^{13}$, ergo do sytuacji takiej nie mają zastosowania przepisy odnoszące się do przewozu. Nie wyłącza to oczywiście możliwości żądania przez podróżującego bez biletu naprawienia szkody na podstawie przepisów odnoszących się do czynów niedozwolonych (art. 415 i n. k.c.), gdyby doszło do jej wyrządzenia przez przewoźnika ${ }^{14}$.

\section{STANOWISKO TRYBUNAŁU SPRAWIEDLIWOŚCI UNII EUROPEJSKIEJ}

Nie sposób podzielić poglądu zaprezentowanego w wyroku Trybunału Sprawiedliwości Unii Europejskiej z 7 listopada 2019 r. ${ }^{15}$, wydanym na skutek pytania prejudycjalnego, dotyczącego podobnego problemu prawnego, a mianowicie: czy art. 9 ust. 4 rozporzadzenia $\mathrm{nr} 1371 / 2007^{16} \mathrm{w}$ zw. z art. 2 lit. a) i art. 3 dyrektywy 93/13 ${ }^{17}$ należy interpretować w ten sposób, że między pasażerem a przewoźnikiem kolejowym w każdym wypadku powstaje stosunek prawny o charakterze umownym, nawet jeśli pasażer korzysta z usług świadczonych przez przewoźnika bez zakupu biletu? Przepis art. 9 ust. 4 rozporządzenia stanowi, że przedsiębiorstwa kolejowe zapewniają możliwość nabycia w pociagu biletów na dane połączenie, chyba że możliwość taka jest ograniczona albo wyłączona ze względów bezpieczeństwa lub zwalczania nadużyć, z powodu obowiązku wcześniejszej rezerwacji lub z uzasadnionych względów handlowych. W kontekście postawionego pytania warto przywołać także treść art. 6 ust. 2 Tytułu II (załącznik I) rozporządzenia, według którego umowę przewozu potwierdza się jednym lub kilkoma biletami na przewóz wydawanymi podróżnemu. Jednakże brak biletu, nieprawidłowości lub utrata biletu nie

12 Jednoznaczne stanowisko w tej kwestii zajmuje zwłaszcza Jaworski (2012): 48-49 oraz Ambrożuk (2014): 145.

${ }^{13}$ Ambrożuk (2014): 84-85; Jaworski (2012): 48-49; Szanciło (2008): 40-41; Górski, Wesołowski (2009): 57-58.

14 Szanciło (2008): 41.

15 Wyrok TSUE z 7 listopada 2019 r., Nationale Maatschappij der Belgische Spoorwegen.

16 Rozporządzenie WE Parlamentu Europejskiego i Rady z 23 października 2007 r. dotyczące praw i obowiązków pasażerów w ruchu kolejowym, Dz. Urz. UE L 2007.315.14 (dalej jako: rozporządzenie).

17 Dyrektywa Rady 93/13/EWG z 5 kwietnia 1993 r. w sprawie nieuczciwych warunków w umowach konsumenckich, Dz. Urz. UE L 1993.95.29 (dalej jako: dyrektywa). Wskazane przepisy stanowia, że warunki umowy, które nie były indywidualnie negocjowane, mogą być uznane za nieuczciwe, jeśli stoją w sprzeczności z wymogami dobrej wiary, powodują znaczącą nierównowagę wynikających z umowy praw i obowiązków stron ze szkodą dla konsumenta. Warunki umowy zawsze zostaną uznane za niewynegocjowane indywidualnie, jeżeli zostały sporządzone wcześniej i konsument nie miał w związku z tym wpływu na ich treść, zwłaszcza jeśli zostały przedstawione konsumentowi w formie uprzednio sformułowanej umowy standardowej. 
powodują nieważności umowy przewozu, która nie naruszając postanowień art. 9, podlega postanowieniom przepisów ujednoliconych. Zgodnie zaś z ustępem trzecim, z zastrzeżeniem dowodu przeciwnego, bilet jest miarodajnym dowodem zawarcia oraz treści umowy przewozu. Funkcja biletu w rozporzadzeniu jest zatem podobna do jego funkcji określonej przez polski porządek prawny, co pozwala na przeniesienie argumentacji zaprezentowanej w punkcie II niniejszego artykułu na grunt unijny.

Trybunał na zadane pytanie odpowiedział twierdząco, uzasadniając, że bilet jest jedynie instrumentem stanowiącym materialny wyraz umowy przewozu, a celem rozporządzenia jest w szczególności zabezpieczenie praw pasażerów w ruchu kolejowym oraz osiagnięcie wysokiego poziomu ochrony konsumentów w dziedzinie transportu. Natomiast uznanie, że pojęcie umowy przewozu należy interpretować w ten sposób, że nie obejmuje ono sytuacji, w której pasażer wsiada do swobodnie dostępnego pociagu w celu odbycia podróży bez zakupienia biletu, byłoby sprzeczne z tymi celami. Zdaniem Trybunału: „gdyby bowiem można było uznać, że taki podróżny, z tego tylko powodu, że nie posiada biletu w momencie wchodzenia na pokład pociagu, nie jest stroną stosunku umownego z przedsiębiorstwem kolejowym, które pozostawiło swoje pociagi do swobodnego dostępu, pasażer ten mógłby, w przypadku wystapienia okoliczności, za które nie można mu przypisać odpowiedzialności, być pozbawiony praw, które rozporządzenie to wiąże z zawarciem umowy przewozu, co naruszałoby cel ochrony pasażerów w ruchu kolejowym realizowany przez to rozporządzenie i przypomniany w motywach 1-3 tego aktu"18. O ile zgodzić należy się z twierdzeniem, że bilet pełni funkcje jedynie dowodową i w konkretnym przypadku możliwe jest skuteczne zawarcie umowy przewozu mimo jego braku (przykłady takich sytuacji zostały podane powyżej oraz w cytowanym orzeczeniu), o tyle pewne wattpliwości budzić może zaprezentowane w tym wywodzie wnioskowanie. Ze zdania, że istnieje taki $x$, że $x$ nie ma biletu i $x$ zawarł skutecznie umowę przewozu, nie wynika jeszcze zdanie, że każdy $x$, który nie ma biletu, zawarł skutecznie umowę przewozu ${ }^{19}$. W przywołanym orzeczeniu zabrakło zastanowienia się nad tym, jakie są warunki konstytutywne zawarcia takiej umowy.

Dużo bardziej przekonujaca wydaje się w tej materii opinia rzecznika generalnego TSUE ${ }^{20}$, zgodnie z która żaden przepis prawa unijnego nie określa, kiedy stosunek prawny można uznać za umowę przewozu, ani nie określa momentu, w którym umowę przewozu można uznać za zawartą. Dyrektywa zakłada jedynie istnienie porozumienia umownego na potrzeby zastosowania przepisów regulujących nieuczciwe warunki umów, nie precyzując, kiedy dochodzi do jego zawarcia. W związku z tym to w gestii sądów państw członkowskich leży ocena, czy w świetle prawa krajowego doszło do powstania stosunku umownego, choć można mieć wątpliwości, czy w sytuacji przejazdu „na gapę”

\footnotetext{
18 Por. wyrok TSUE z 7 listopada 2019 r., Nationale Maatschappij der Belgische Spoorwegen.

${ }^{19}$ Duży kwantyfikator daje się zastapić małym kwantyfikatorem, ale implikacja ta nie zachodzi w drugą stronę. Por. np. Patryas (2003): 64.

${ }^{20}$ Opinia rzecznika generalnego Giovanniego Pitruzzelli przedstawiona 11 czerwca 2019 r. w sprawach połączonych od C-349/18 do C-351/18, EU:C:2019:478.
} 
mogła mieć w ogóle miejsce właściwa wymiana wzajemnych oświadczeń woli, która stanowiłaby umowę. Podróżny w rzeczywistości nie wyraża zgody na zasadnicze postanowienia umowy, a mianowicie na cenę usługi i na uiszczenie tej opłaty. Z kolei zamiarem przewoźnika nie jest świadczenie usług przewozu nieodpłatnie. Rzecznik zwrócił ponadto uwagę na istotną kwestię, że zachowanie pasażera, który wsiada do pociagu, świadomie nie zakupiwszy biletu i bez zamiaru wywiązania się z obowiązku zapłaty ceny za usługę, z której korzysta, pomimo różnych możliwości, jakie oferuje mu usługodawca w trakcie lub po zakończeniu korzystania z samej usługi, ma negatywną konotację społeczną i w różnych systemach prawnych może być prawnie zakwalifikowane jako zwykłe naruszenie umowy, jako delikt administracyjny lub nawet przestępstwo $^{21}$. Skoro wynik wykładni językowej nie burzy ocen przypisywanych racjonalnemu prawodawcy, gdyż nie istnieją względy słuszności, przemawiajace za szczególną ochrona osoby, która wyłudza świadomie przejazd i nie zamierza za niego zapłacić, to nie ma potrzeby przełamywać tego wyniku, twierdzac, że art. 9 ust. 4 rozporządzenia oraz art. 2 lit. a) i art. 3 dyrektywy należy interpretować w ten sposób, że między przedsiębiorstwem przewozowym a podróżnym zawsze istnieje stosunek umowny. Wszak sytuacja takiej osoby bardziej przypomina przywołany już kazus złodzieja kradnącego towar ze sklepu, któremu nikt nie próbuje podczas tej czynności przypisywać statusu konsumenta.

\section{CHARAKTER PRAWNY OPLATY DODATKOWEJ}

Czym zatem jest opłata dodatkowa, której istnienie wynika wprost z art. 33a ust. 3 Pr.przew.? W doktrynie występują rozmaite poglądy. Niektórzy autorzy ${ }^{22}$ proponuja uznanie jej za karę umowna albo ustawowa, co jest koncepcją chybiona. Już prima facie należy bowiem odrzucić możliwość zastosowania w analizowanej sytuacji art. $483 \S 1$ k.c., ponieważ zgodnie z jego dyspozycją kara umowna powstaje wyłącznie w wyniku zawarcia umowy ${ }^{23}$. Dogłębniejszego rozważenia wymaga koncepcja uznająca opłatę dodatkową za karę ustawową. Zgodnie z brzmieniem art. 485 k.c. źródłem kary ustawowej sa przepisy szczególne ${ }^{24}$, zatem ta przesłanka jest w omawianym przypadku spełniona. Jednakże, podobnie jak kara umowna, również ta instytucja doty-

${ }^{21}$ Postanowienie z 30 maja 2018 r., SNCB, C-190/18, niepublikowane, EU:C:2018:355: pkt 7; wyrok z 21 września 2016 r., Nationale Maatschappij der Belgische Spoorwegen, C 261/15, EU:C:2016:709: pkt 12 i 13.

22 Ostrowska (1998): 16.

${ }^{23} \mathrm{~W}$ literaturze i orzecznictwie wątpliwości budzi kwestia, czy postanowienie zastrzegające karę umowną może zostać zawarte także we wzorcu umownym, por. wyrok SN z 25 maja 2007 r., I CSK 484/06, Lex nr 320037, w którym stwierdzono, że „nie jest dozwolone zastrzeganie we wzorcu umownym kary umownej rażąco wygórowanej”; krytycznie Popiołek (2018): 96; za możliwością zastrzeżenia kary umownej we wzorcu umownym (o ile spełnione zostały zasady inkorporacji przewidziane w art. 384 i n. k.c.) opowiada się także Lemkowski (2019): 1134.

${ }^{24}$ Choć obecnie w systemie prawa prywatnego niewiele jest takich przepisów, por. Lemkowski (2019): 1146. Przykładem z obszaru prawa przewozowego jest zryczałtowane odszkodowanie 
czy wyłącznie niewykonania lub nienależytego wykonania zobowiązań niepieniężnych. Natomiast zobowiązanie „gapowicza” może być realizowane tylko w pieniądzu, w związku z czym i tę próbę określenia charakteru opłaty dodatkowej należy odrzucić.

Bardzo ostrożnie należy także podejść do propozycji stosowania per analogiam art. 485 k.c. do sankcji w zakresie zobowiązań pieniężnych ${ }^{25}$. Wnioskowanie w drodze analogia iuris wymaga zawsze odwołania się do systemu wartości przypisywanych racjonalnemu prawodawcy i wykazania, że w systemie prawnym obowiązuje także norma niewysłowiona expressis verbis $\mathrm{w}$ przepisach, która znajduje uzasadnienie aksjologiczne w tych samych ocenach co normy wyraźnie ustanowione przez prawodawcę ${ }^{26}$. Może przy tym powstać niepewność co do tego, jaką wartość realizują czyny będące przedmiotem obowiązków wyrażonych w normach-przesłankach i czy owa wartość na pewno uzasadnia obowiązywanie normy-konsekwencji. Niezasadne byłoby także charakteryzowanie analizowanego uprawnienia przewoźnika jako uprawnienia kształtującego, ponieważ prawa kształtujące znamionuje to, że podmiotowi uprawnionemu przysługuje kompetencja do zmiany lub zakończenia istniejacego stosunku prawnego przez jednostronną czynność prawną ${ }^{27}$, a nie do jego powstania - jak w rozpatrywanej sytuacji.

Inne stanowisko co do charakteru opłaty dodatkowej zaprezentował Adam Jaworski, twierdząc, że dla ustalenia reżimu prawnego odpowiedzialności pasażera zasadne wydaje się analogiczne zastosowanie przepisów o bezpodstawnym wzbogaceniu ${ }^{28}$. W przypadku przejazdu bez uiszczenia wymaganych należności przewoźnik wykonuje bowiem na rzecz podróżnego świadczenie bez podstawy prawnej w rozumieniu art. $410 \S 2$ k.c. W konsekwencji Jaworski przyjmuje, że opłatę dodatkową można uznać za najbliższą zryczałtowanemu zwrotowi bezpodstawnego wzbogacenia ${ }^{29}$. O ile zgodzić się można z teza, że w rozpatrywanej sytuacji przewoźnik faktycznie spełnia świadczenie, mimo że nie był do tego w ogóle zobowiązany (condictio indebiti) ${ }^{30}$, gdyż - jak zostało wykazane powyżej - podmiotów tych nie wiąże umowa przewozu, o tyle nie sposób uznać opłaty dodatkowej za zryczałtowany zwrot nienależnego świadczenia. Tytułem bezpodstawnego wzbogacenia uprawniony mógłby domagać się wydania korzyści w naturze, a gdyby to nie było możliwe, do zwrotu jej wartości. W przypadku wyłudzenia przejazdu jedyną korzyścia, jaką ewentualnie odnosi pasażer jadący „na gapę”, jest brak uiszczenia opłaty za przejazd ${ }^{31}$.

płacone przez przewoźników z tytułu nienależytego wykonania świadczenia przewozowego, por. Popiołek (2018): 110-11.

${ }^{25}$ Tak Lemkowski (2019): 1146, który podaje przykład art. 10 ust. 1 ustawy z 8 marca 2013 r.

o terminach zapłaty w transakcjach handlowych, Dz. U. 2013, poz. 403.

${ }^{26}$ Wronkowska (2005): 95-96.

${ }^{27}$ Radwański, Olejniczak (2013): 89-90.

${ }^{28}$ Jaworski (2012): 77.

29 Jaworski (2012): 77.

${ }^{30}$ Szerzej na temat wskazanej kondykcji zob. w szczególności Mularski (2019): 464-467; Sokołowski (2014): 376-377.

${ }^{31}$ Mimo że w nauce i orzecznictwie przeważa stanowisko traktujace bezumowne korzystanie z usług (które nie wpływają w żaden sposób na wartość majątku korzystającego) jako przykład 
Gdyby uznać za trafną propozycję, że w takim przypadku zastosowanie znajda przepisy o bezpodstawnym wzbogaceniu, żądanie przewoźnika mogłoby dotyczyć co najwyżej kosztu przejazdu, jaki poniósłby pasażer w normalnym biegu zdarzeń ${ }^{32}$, wynikająca zaś z Prawa przewozowego opłata dodatkowa opiewa na wartość znacznie wyższą.

Wobec trudności z zakwalifikowaniem opłaty dodatkowej jako konkretnej instytucji prawa cywilnego pojawiły się publikacje opisujące ją wyrażeniem: „sankcja cywilnoprawna sui generis” ${ }^{33}$. Wydaje się, że stanowisko to, mimo pewnej ogólnikowości, powinno zostać uznane za poprawne. Jednakże i przy tym określeniu mogą pojawić się wątpliwości, jeżeli uwzględni się pewne intuicje związane z literalnym brzmieniem art. 33a ust. 3 Pr.przew., którego warstwa tekstowa prima facie bliższa jest aktom normatywnym z zakresu prawa publicznego. Rozważyć zatem należy, czy powstały na jej tle stosunek prawny ma charakter cywilnoprawny czy też może administracyjnoprawny.

Próbując udzielić odpowiedzi na postawione wyżej pytanie, należy przeanalizować następujące kwestie: podmioty stosunku prawnego, ich wzajemna pozycję (relację), przedmiot stosunku prawnego oraz powstanie tego stosunku (dobrowolność jego nawiązywania i korzystania z przyznanych uprawnień) ${ }^{34}$.

Źródłem obowiązku uiszczenia opłaty dodatkowej jest art. 33a ust. 3 Pr.przew. Jego doprecyzowanie w odniesieniu do podmiotów realizujących regularny przewóz osób na obszarach jednostek samorządu terytorialnego znajduje się w zarządzeniach organów wykonawczych oraz uchwałach odpowiednich organów kolegialnych jednostek samorządu terytorialnego. W stosunku do pozostałych podmiotów, w tym prywatnych przewoźników, obowiązek ten został natomiast dookreślony w rozporządzeniu Ministra Infrastruktury z 20 stycznia 2005 r. w sprawie sposobu ustalania wysokości opłat dodatkowych z tytułu przewozu osób, zabranych ze sobą do przewozu rzeczy i zwierząt oraz wysokości opłaty manipulacyjnej ${ }^{35}$. Za przykład rozwiązań na poziomie samorządu

wzbogacenia (por. Sokołowski (2014): 348; Księżak (2017): 389; Ohanowicz (1956): 365; wyroki SN: z 12 czerwca 1975 r., III CRN 479/74, OSP 1976, nr 7/8, poz. 149; z 25 lutego 2004 r., I CK 212/03, Lex nr 176088; z 30 stycznia 2007 r., I CSK 221/06, MoP 2008, nr 17: 942; z 2 sierpnia 2007 r., 152/07, OSG 2008, nr 12, poz. 98: 3), to w przypadkach tych wątpliwości może budzić, czy podmiot taki rzeczywiście odnosi jakąkolwiek korzyść majątkowa, czy też może jedyną konsekwencją takiego zdarzenia jest po prostu to, że aktywa usługobiorcy nie ulegają zwiększeniu, tak Mularski (2019): 421-422.

${ }^{32} \mathrm{Z}$ uwagi na inny cel niniejszego artykułu autorzy nie chcą wchodzić w spór dotyczący słuszności „tezy o niższej wartości”, tj. poglądu, że, gdy wartość zubożenia różni się od wartości wzbogacenia, roszczenie zubożonego (solvensa) ogranicza się do niższej z obu wartości, tak w odniesieniu do nienależnego świadczenia Łętowska (2000): 94; Mularski (2019): 416 i 460-462; Mostowik (2014): 313; w myśl tej koncepcji roszczenie przewoźnika opiewałoby wyłącznie na wysokość kosztów, jakie wygenerowało przewiezienie o jednego pasażera więcej (ewentualny wzrost zużycia paliwa). Odmiennie zob. np. wyroki SN: z 24 listopada 2011 r., I CSK 66/11, Lex nr 1133784; z 29 listopada 2016 r., I CSK 798/ 15, Lex nr 2183475; z 11 maja 2017 r., II CSK 541/16, Lex nr 2329450; w orzeczeniach tych przyjęto, że w sytuacji gdy wzbogacenie przybrało postać nienależnego świadczenia, w ogóle nie jest konieczne ustalanie wysokości zubożenia podmiotu spełniającego nienależne świadczenie.

${ }^{33}$ Radwański (1998): 16; Ambrożuk (2014): 145-146; Jaworski (2012): 77.

34 Podobne kryteria proponuje Hauser (2015): 201.

35 Dz. U. 2005, nr 14, poz. 117. 
terytorialnego niech posłuży $§ 10$ zarządzenia nr 344/2014/P Prezydenta Miasta Poznania z 11 czerwca 2014 r. Wysokość opłaty, a dokładniej sposób określania jej wysokości ${ }^{36}$, w odniesieniu do gminnego, powiatowego i wojewódzkiego regularnego przewozu osób, określają odpowiednio: rada gminy, rada powiatu albo sejmik województwa, a w mieście stołecznym Warszawie - Rada miasta stołecznego Warszawy (art. 34a ust. 2 Pr.przew.). Zatem, przykładowo, w przypadku Poznania kwota opłaty dodatkowej wynika z § 1 pkt 1 Uchwały Rady Miasta Poznania nr XIX/248/VII/2015 z 3 listopada 2015 r. w sprawie sposobu ustalania w lokalnym transporcie zbiorowym wysokości opłat dodatkowych z tytułu przewozu osób, naruszenia przepisów o przewozie rzeczy i zwierząt oraz w sprawie wysokości opłaty manipulacyjnej (Dz. Urz. Woj. Wielkopolskiego 2015, poz. 6657). Wskazane zaś uchwały, zarówno w opinii autorów, jak i zdaniem doktryny $^{37}$, stanowia akty prawa miejscowego, zgodnie z art. 40 ust. 1 i art. 41 ust. 1 ustawy o samorządzie gminnym (Dz. U. 2019, poz. 506).

Sam fakt, że przepis prawa powszechnie obowiązującego łączy z określonym zdarzeniem powstanie obowiązku danego podmiotu, nie przesądza bynajmniej o tym, że takie zobowiązanie ma publicznoprawny charakter. Również w prawie prywatnym pojawiaja się takie przypadki, gdy nawiązanie stosun$\mathrm{ku}$ prawnego nie jest dobrowolne (np. stosunek alimentacyjny nawiąuje się z mocy ustawy między osobami połaczonymi węzłem rodzinnym ${ }^{38}$ ). Za niespotykana, ale również nieprzesądzającą definitywnie o charakterze stosunku prawnego, można uznać okoliczność, że wysokość świadczenia wynika w części tych przypadków z aktów prawa miejscowego, które na ogół nie stanowią źródła prawa prywatnego, choć oczywiście nie można wykluczyć a limine takiej sytuacji ${ }^{39}$.

Kolejne wątpliwości budzi to, że przepis art. 33a ust. 3 Pr.przew. jest tzw. przepisem kompetencyjnym pluralnym, tzn. zawiera w sobie dwie normy prawne: jedna - upoważniająca wymienione w nim podmioty do pobrania opłaty dodatkowej albo wystawienia wezwania do zapłaty w określonych okolicznościach oraz druga - nakazująca im z tej kompetencji korzystaćc ${ }^{40}$. W ramach stosunków prawa cywilnego materialnego relatywnie rzadko występuja sytuacje, w których ustawa nakłada na podmiot uprawniony obowiazek dochodzenia należnego mu roszczenia, jest to metoda regulacji bardziej charakterystyczna dla prawa publicznego.

Funkcja opłaty dodatkowej także nie jest typowa dla prawa cywilnego. Z uwagi na to, że wysokość opłaty znacząco przewyższa uszczerbek (utracone korzyści) przewoźnika, należy stwierdzić, że pełni ona w istocie funkcję represyjną (penalna) ${ }^{41}$, ponieważ stanowi formę ukarania „gapowicza”, oraz funkcję

${ }^{36}$ Wyrok NSA z 6 kwietnia 2010 r., II GSK 518/09, Lex nr 596900.

37 Ambrożuk (2104): 152.

38 Smyczyński (2011): 754-756.

39 Safjan (2012): 207.

${ }^{40}$ Szerzej na temat przepisów pluralnych zob. Zieliński (2017): 108-109; a w kwestii odkodowywania norm kompetencyjnych por. Wronkowska (2005): 83-84.

41 Ambrożuk (2014): 145; Jaworski (2012): 76; Górski, Wesołowski (2009): 102; w podobnym kierunku Szanciło (2008): 176. 
prewencyjna - ma odstraszać inne osoby, które mogłyby chcieć wyłudzić przejazd. W związku z tym jej charakter zbliża się funkcjonalnie do charakterystycznych dla amerykańskiego systemu prawnego odszkodowań karnych (ang. punitive damages); mają one również na celu odstraszanie społeczeństwa od złego zachowania i ukaranie sprawcy, który umyślnie postapił w sposób niewłaściwy, nieusprawiedliwiony, złośliwy czy podstępny ${ }^{42}$. Penalną funkcję opłaty dodatkowej potwierdza także powszechne w judykaturze i doktrynie ${ }^{43}$ kwalifikowanie jej jako kary pieniężnej na gruncie art. $121 \S 1$ Kodeksu wykroczeń ${ }^{44}$.

W kwestii przedmiotu rozpatrywanego stosunku prawnego zauważyć należy, że organizacja transportu lokalnego stanowi jedno z zadań jednostek samorządu terytorialnego każdego szczebla (por. np. art. 7 ust. 1 pkt 4 ustawy o samorządzie gminnym). Tym samym sprawa przedmiotowo należy do sfery działania administracji i jest dopuszczona do regulowania w trybie nakazów czy zakazów administracyjnych, co odpowiada dwóm cechom wskazywanym w literaturze jako wyznaczniki przedmiotu stosunku administracyjnoprawnego ${ }^{45}$.

Rozstrzygającego argumentu przy kwalifikacji opłaty dodatkowej dostarcza jednak, jak się zdaje, analiza podmiotów powstałego na jej tle stosunku prawnego. Przewoźnik może być podmiotem publicznym (np. zakładem budżetowym jednostki samorządu terytorialnego) albo prywatnym - osobą fizyczną prowadzącą działalność gospodarczą czy też osobą prawną albo jednostka organizacyjną wyposażoną przez ustawę w zdolność prawną. Także w przypadku przewoźnika prywatnego może się zdarzyć, że prowadzona przez niego działalność będzie stanowiła realizację zadania własnego jednostki samorządu terytorialnego na mocy zawartych z nim przez tę jednostkę umów (tzw. administracja funkcjonalna ${ }^{46}$ ). Jednakże, co do zasady, uczestnictwo w stosunku prawnym wyłącznie podmiotów prywatnych będzie wykluczało zakwalifikowanie tego stosunku jako publicznoprawnego.

Warto zauważyć, że nawet w przypadku gdy przewoźnikiem jest podmiot publiczny (np. spółka komunalna), relacja podmiotów stosunku prawnego jest - przynajmniej z formalnego punktu widzenia - równorzędna. Przewoź-

${ }^{42}$ Zob. Kochanowski (2018): 3-5, 8-9; Adrych-Brzezińska (2018): 372-379. Z drugiej strony, o ile odpowiedzialność karna w systemach common law wiąże się z intencjonalnym sprawstwem, o tyle odpowiedzialność na podstawie art. 33a ust. 3 Pr.przew. ma charakter obiektywny, ponieważ przesłanką roszczenia o zapłatę opłaty dodatkowej jest brak odpowiedniego dokumentu, niezależnie od tego, czy ów brak jest zawiniony przez podróżnego, por. Jaworski (2012): 77.

${ }^{43}$ Zob. Bojarski (2020): 550; Zbrojewska (2013): 569; wyroki SN: z 6 lipca 1995 r., III KRN 56/95, Lex nr 24569; z 27 marca 2013 r., II KK 58/13, OSNKW 2013, nr 3, poz. 46; wyrok SO w Poznaniu z 8 stycznia 2015 r., XVII Ka 1313/14, Lex nr 1837904; wyrok SO w Białymstoku z 7 lutego 2013 r., VIII Ka 960/12, Lex nr 1712751.

${ }_{44}$ T.jedn.: Dz. U. 2019, poz. 821.

45 Starościak (1978): 16.

${ }^{46}$ Por. Stahl (2011: 536): „Podmiot niepubliczny, wykonując zadania administracji publicznej, pozostaje podmiotem prywatnym, ale w sensie funkcjonalnym ma charakter podmiotu administrującego i staje się - w tym jedynie zakresie - podmiotem administrującym, elementem funkcjonalnie rozumianego systemu administracji publicznej”. 
nik nie ma prawa orzekania i przesądzania w sposób wiążący o sytuacji pasażera jadącego „na gapę”. W razie braku zgody co do rozwiąania spraw spornych w ramach stosunku spory te rozstrzyga podmiot stojaccy na zewnątrz tego stosunku, czyli sąd powszechny. Inaczej niż w stosunku administracyjnoprawnym, w którym sprawy sporne $\mathrm{z}$ określonym przez prawo skutkiem prawnym rozstrzyga jedna ze stron stosunku - organ administracji publicznej ${ }^{47}$. Charakteru postępowania administracyjnego nie należy przypisywać postępowaniu reklamacyjnemu, wywołanemu zgłoszeniem „gapowicza”, który kwestionuje otrzymane wezwanie do zapłaty, ponieważ podmiot załatwiający reklamację nie jest uprawniony do rozstrzygania sporów, w których sam jest strona ${ }^{48}$. Reklamacja jest jedynie wezwaniem do dobrowolnego spełnienia świadczenia (instytucja prawa cywilnego materialnego wywołująca także pewne skutki procesowe ${ }^{49}$ ), nie stanowi żądania udzielenia ochrony prawnej dla zgłoszonego w niej roszczenia. W postępowaniach reklamacyjnych nie orzeka się zatem o niczym, a tym samym ich wynik - z wyjątkiem sytuacji, gdy dojdzie do dobrowolnego zaspokojenia roszczenia - nie ma żadnego wpływu na mogące nastąpić po nim postępowanie sądowe (brak skutku prejudycjalnego $)^{50}$.

Interesujaca kwestią jest, że obowiązek zapłaty opłaty dodatkowej nie pojawia się w momencie przejazdu bez wymaganego dokumentu przewozu, lecz dopiero w razie stwierdzenia braku takiego dokumentu przez osobę upoważnioną przez przewoźnika. Takie ujęcie okoliczności, w których norma znajduje zastosowanie, może sprawiać wrażenie, jakoby przewoźnik miał kompetencję do przesądzania w sposób autorytatywny o sytuacji drugiego podmiotu stosunku. Zauważyć jednak należy, że przewoźnik nie decyduje w tym przypadku o sytuacji prawnej „gapowicza”, a jedynie stwierdza element stanu faktycznego, z czym dopiero ustawa wiaże skutek prawny w postaci powstania określonego stosunku prawnego.

Analizowany problem nie jest tylko i wyłącznie specyfiką polska, ale wystapił także w powoływanym już powyżej wyroku TSUE z 7 listopada 2019 r. w połączonych sprawach C-349/18 do C-351/17, w którym to wyroku zauważono, że podstawa prawna ogólnych warunków przewozu w prawie belgijskim nie jest jasna. Zgodnie $\mathrm{z}$ jedna $\mathrm{z}$ tez są to klauzule o charakterze czysto umownym, zgodnie $\mathrm{z}$ druga - rozporządzenia $\mathrm{w}$ rozumieniu prawa administracyjnego, a stosunek łączący pasażera, który nie ma zamiaru uiścić zapłaty za przewóz z przewoźnikiem, ma charakter regulacyjny ${ }^{51}$.

${ }^{47}$ Starościak (1977): 19-20; Longchamps (1964): 47.

${ }^{48}$ Więckowski (1990): 57; Szanciło (2008): 356-357; Górski, Wesołowski (2009): 350: „Postępowanie reklamacyjne nie ma nic wspólnego z postępowaniem procesowym ani z postępowaniem administracyjnym”; Jaworski (2012: 149): „Postępowanie reklamacyjne nie jest postępowaniem o charakterze władczym".

${ }^{49}$ Brak wniesienia reklamacji powoduje czasową niedopuszczalność drogi sądowej, por. Jaworski (2012): 149; Szanciło (2008): 358.

${ }^{50}$ Więckowski (1990): 57.

${ }^{51}$ Wyrok TSUE z 7 listopada 2019 r., Nationale Maatschappij der Belgische Spoorwegen. 


\section{WNIOSKI}

Rozpatrywane w ramach artykułu zagadnienie, choć prima facie może wydawać się dość szczegółową kwestia, to przy wnikliwej analizie prowadzi do bardziej ogólnych rozważań dotyczących podstawowych pojęć prawa cywilnego, takich jak oświadczenie woli czy czynność prawna. Jednocześnie, mając na uwadze, że w znacznej liczbie przypadków analizowany stosunek prawny powstaje między osobą fizyczną a organizatorem transportu publicznego lub przewoźnikiem realizującym zadania własne jednostki samorządu terytorialnego w zakresie transportu publicznego, konieczne okazało się także ustalenie kryteriów rozróżniania stosunków publicznoprawnych i cywilnoprawnych.

Poczynione rozważania zamykają się w następujących konkluzjach. Relacja przewoźnika i „gapowicza” zdecydowanie nie ma charakteru umownego, samo zaś wejście do pojazdu, w sytuacji kiedy określone zostały warunki dostępu do środka transportowego, nie stanowi oświadczenia woli zawarcia umowy (scil. przyjęcia oferty zawarcia umowy przewozu złożonej ad incertas personas przez przewoźnika). Interpretacja art. 16 Pr.przew. nie pozostawia co do tego wątpliwości. Zobowiązanie „gapowicza” ma jednak charakter cywilnoprawny i wydaje się, że należy zakwalifikować je jako wynikajace z innego niż bezpodstawne wzbogacenie, negotiorum gestio, czy też delikt pozaumownego źródła powstania zobowiązania.

Opłata dodatkowa stanowi sankcję cywilnoprawną sui generis o nietypowych dla prawa prywatnego cechach. Realizuje rzadziej występujace w polskim porządku cywilnoprawnym funkcje, będąc wyraźnie represyjno-prewencyjnym narzędziem, w założeniu przeciwdziałajacym wyłudzaniu przejazdów środkami transportu. Dodatkowo obowiązek uiszczenia opłaty dodatkowej powiązany jest z szeregiem elementów charakterystycznych dla prawa publicznego. Należą do nich: aktualizacja obowiązku świadczenia dopiero w razie stwierdzenia braku dokumentu przewozu (a nie w razie samego wyłudzenia usługi), jak również określenie wysokości zobowiązania w akcie prawa miejscowego. Podobnie powinność pobrania opłaty przez przewoźnika oraz przedmiot realizowanej działalności, stanowiący jedno z zadań własnych samorządu terytorialnego, upodabniają obowiązek z art. 33a ust. 3 Pr.przew. do zobowiązania publicznoprawnego. Jednakże powszechność adresatów ustawy - Prawo przewozowe i w konsekwencji objęcie zakresem jej zastosowania również przewoźników prywatnych, nierealizujących zadań z zakresu administracji publicznej, implikuje niemożność stwierdzenia administracyjnoprawnego charakteru opłaty dodatkowej.

Adrych-Brzezińska, I. (2018). Odszkodowanie karne - sposób na efektywniejsze prawo czy efektowny amerykański partykularyzm prawny? Gdańskie Studia Prawnicze 39: 371-385.

Ambrożuk, D. (2014). Przewóz osób i przesyłek bagażowych, [w:] D. Ambrożuk, D. Dąbrowski, K. Wesołowski (red.), Prawo przewozowe. Komentarz. Warszawa: 73-152.

Bojarski, T. (2019). Kodeks wykroczeń. Komentarz. Warszawa. 
Górski, W., Wesołowski, K. (2009). Komentarz do przepisów o umowie przewozu i spedycji Kodeks cywilny - Prawo przewozowe - CMR. Gdańsk.

Hauser, R. (2015). Stosunek administracyjnoprawny, [w:] R. Hauser, Z. Niewiadomski, A. Wróbel (red.), System prawa administracyjnego. Tom 1: Instytucje prawa administracyjnego. Warszawa: 199-218.

Jaworski, A. (2012). Prawo przewozowe. Komentarz. Warszawa.

Kochanowski, M. (2018). Rozważania na temat represyjnych i prewencyjnych elementów odpowiedzialności odszkodowawczej na przykładzie instytucji odszkodowania karnego (punitive damages) w świetle orzeczenia Sądu Najwyższego oraz Trybunału Konstytucyjnego. Studia Prawa Publicznego 06/13: 83-100.

Księżak, P. (2017). Bezpodstawne wzbogacenie, [w:] K. Osajda (red.), Kodeks cywilny. Komentarz. Zobowiązania. Część ogólna. Warszawa: 347-514.

Lemkowski, M. (2019). Wykonanie zobowiązań i skutki ich niewykonania, [w:] M. Gutowski (red.), Kodeks cywilny. Tom 2: Komentarz. Art. 353-626. Warszawa: 988-1203.

Longchamps, F. (1964). O pojęciu stosunku prawnego w prawie administracyjnym. Acta Universitatis Wratislaviensis, Prawo 12: 41-49.

Łętowska, E. (2000). Bezpodstawne wzbogacenie. Warszawa.

Mostowik, P. (2014). Bezpodstawne wzbogacenie, [w:] A. Olejniczak (red.), System prawa prywatnego. Tom 6: Prawo zobowiązań - część ogólna. Warszawa: 215-340.

Mularski, K. (2019). Bezpodstawne wzbogacenie, [w:] M. Gutowski (red.), Kodeks cywilny. Tom 2: Komentarz. Art. 353-626. Warszawa: 407-500.

Ohanowicz, A. (1956). Niesłuszne wzbogacenie. Warszawa.

Ostrowska, M. (1998). Opłata dodatkowa to kara umowna. Rzeczpospolita 4: 16.

Patryas, W. (2003). Elementy logiki dla prawników. Poznań.

Popiołek, W. (2018). Wykonanie zobowiązań i skutki ich niewykonania, [w:] K. Pietrzykowski (red.), Kodeks cywilny. Tom 2: Komentarz. Art. 450-1088. Przepisy wprowadzające. Warszawa: 3-137.

Radwański, M. (1998). Kontrowersje wokół opłaty dodatkowej. Rzeczpospolita 6: 19.

Radwański, Z., Mularski, K. (2019). Zagadnienia ogólne czynności prawnych, [w:] Z. Radwański, A. Olejniczak (red.), System prawa prywatnego. Tom 2: Prawo cywilne - część ogólna. Warszawa: $1-60$.

Radwański, Z., Olejniczak, A. (2013). Prawo cywilne - część ogólna. Warszawa.

Radwański, Z., Panowicz-Lipska, J. (2013). Zobowiązania - część szczegółowa. Warszawa.

Safjan, M. (2012). Źródła prawa prywatnego, [w:] M. Safjan (red.), System prawa prywatnego. Tom 1: Prawo cywilne - część ogólna. Warszawa: 157-254.

Smyczyński, T. (2011). Obowiązek alimentacyjny, [w:] T. Smyczyński (red.), System prawa prywatnego. Tom 12: Prawo rodzinne i opiekuńcze. Warszawa: 751-830.

Sokołowski, T. (2014). Bezpodstawne wzbogacenie, [w:] A. Kidyba (red.), Kodeks cywilny. Tom 3: Zobowiązania. Część ogólna. Warszawa: 344-414.

Stahl, M. (2011). Inne podmioty administrujące, [w:] R. Hauser, Z. Niewiadomski, A. Wróbel (red.), System prawa administracyjnego. Tom 6: Podmioty administrujace. Warszawa: 501-536.

Starościak, J. (1977). Prawo administracyjne. Warszawa.

Starościak, J. (1978), [w:] T. Rabska, J. Łętowski (red.), Stosunek administracyjnoprawny, [w:] System prawa administracyjnego. Tom 3. Wrocław: 16.

Szanciło, T. (2008). Prawo przewozowe. Komentarz. Warszawa.

Więckowski, R. (1990). Sądowe dochodzenie roszczeń a postępowania przedsądowe. Państwo i Prawo 45(2): 52-61.

Wronkowska, S. (2005). Podstawowe pojęcia prawa i prawoznawstwa. Poznań.

Zbrojewska, M. (2013). Komentarz do art. 121 § 1, [w:] T. Grzegorczyk (red.), Kodeks wykroczeń. Komentarz. Warszawa: 569.

Zieliński, M. (2017). Wykładnia prawa. Zasady - reguły - wskazówki. Warszawa.

Ziembiński, Z. (2012). Logika praktyczna. Warszawa. 


\section{THE LEGAL NATURE OF THE ADDITIONAL FEE FOR THE LACK OF AN APPROPRIATE TRANSPORT DOCUMENT}

\section{Sum mary}

The article constitutes an attempt to explain the legal nature of the additional fee for the lack of an appropriate transport document. In the first part of the article, the authors consider what legal relationship, if any, connects the carrier with the person who in fact took a place in the means of transport, but did not intend to pay the transport charges. This is the basis for considering more general issues, such as the definition of a declaration of intent. In this context, the authors criticize the latest rulings by the Court of Justice of the European Union regarding the legal situation of a person travelling without a ticket. Then the authors tackle the issue signalled in the title they attempt to determine the legal nature of the additional fee. To this end, they first review the positions presented in the doctrine to then formulate their own conclusions. First of all, the issue in question requires the boundaries between civil and administrative law to be clarified, and also for some deliberation to be devoted to the purpose of the title fee.

Keywords: additional fee; contract of carriage; declaration of intent; civil law relationship 
